\title{
Degradation in the nozzle materials of subscale motor in a static firing test
}

\author{
Deterioración en los materiales de la boquilla de motor-prueba en ensayo de \\ quema estática
}

Deterioração nos materiais da tubeira de motor-teste em ensaio de queima estática

\author{
Ronald Izidoro Reis, Doctor \\ Institute of Aeronautics and Space - IAE \\ São José dos Campos/SP - Brazil \\ izidororir@iae.cta.br \\ Wilson Kiyoshi Shimote, Master \\ Institute of Aeronautics and Space - IAE \\ São José dos Campos/SP - Brazil \\ wilsonwks@iae.cta.br \\ Luiz Cláudio Pardini, Doctor \\ Institute of Aeronautics and Space - IAE \\ São José dos Campos/SP - Brazil \\ pardinilcp@iae.cta.br
}

\section{ABSTRACT}

This work presents the study conducted at the Institute of Space and Aeronautics, an organization of the Department of Science and Aerospace Technology (DCTA-IAE, in the Portuguese acronym), to investigate the erosion of the thermal protection, nozzle throat insert, and thermal protection of the convergent manufactured in EPDM rubber of the convergent section of the nozzle, during the sub scale solid propellant rocket motor static firing test. During this study, tests were conducted in order to evaluate the performance of the nozzle ablation of insert material and also of the rubber to protect thermally the metallic motor case and also to the convergent, in addition to verifying the functionality of the adhesion between the propellant and the rubber. For the work herein presented, specifically, only the results inherent to the evaluation of the nozzle insert material and the deterioration of the EDPM rubber in the interface with the conducted in order to evaluate the performance of nozzle ablation of insert material, and also of the rubber to protect thermally the metallic motor case and also to the convergent, in addition to verifying the functionality of the adhesion between the propellant and the rubber. For the work herein presented, specifically, only the results inherent to the evaluation of the nozzle insert material and the degradation of the EDPM rubber in the interface with the graphite material insert for a test time of $56 \mathrm{~s}$ will be analyzed. After the tests, non-conformities were detected in components of the engine that subsequently led to a careful analysis of the reasons, as well as to the implementation of solutions for the redesign of components with the aim of improving the safety and assuring the structural integrity of the rocket engine for further tests.

Keywords: VLM-1. Firing test. End-burning test-engine. Graphite material insert.

Received / Recibido / Recebido 03/02/16
Accepted / Aceptado / Aceito 06/13/16

The acronyms and abbreviations contained in this article correspond to the ones used in the original article in Portuguese. 


\section{RESUMEN}

Este trabajo presenta estudio dirigido en el Instituto de Aeronáutica y Espacio, organización del Departamento de Ciencia y Tecnología Aeroespacial (DCTA/IAE), para investigar el consumo de la protección térmica, inserto en la garganta de la boquilla y goma EPDM de la parte convergente de la boquilla, durante ensayo de quema estática del motor-cohete. Durante este estudio fueron hechos ensayos que tenían como objetivo la evaluación del desempeño de la ablación del material del inserto en la garganta de la boquilla y también de la formulación de goma para protección térmica del sobre-motor y del sistema convergente, además de verificar la funcionalidad de la adhesión entre el propelente y la goma. Específicamente para el trabajo aquí presentado, serán analizados solamente resultados inherentes a la evaluación del inserto de la boquilla y deterioración de la goma EPDM en la interface con el inserto de grafito para un tiempo de ensayo de $56 \mathrm{~s}$. Fue verificada, después de ensayos, la presencia de no conformidades en componentes del motor, que, posteriormente, llevaron a un análisis criterioso de sus causas y la implementación de soluciones para re-proyecto de componentes con la intención, así, de aumentar la seguridad y garantir la integridad estructural del motor-cohete para continuidad de los ensayos.

Keywords: VLM-1. Ensayo de quema. Motor-prueba cigarro. Inserto de grafito.

\section{RESUMEN}

O presente trabalho mostra estudo conduzido no Instituto de Aeronáutica e Espaço, organização do Departamento de Ciência e Tecnologia Aeroespacial (DCTA/IAE), para investigar o consumo da proteção térmica, inserto na garganta da tubeira e borracha EPDM da parte convergente da tubeira, durante ensaio de queima estática do motor-foguete. Durante este estudo foram realizados ensaios que visavam à avaliação do desempenho da ablação do material do inserto da garganta da tubeira e também da formulação de borracha para proteção térmica do envelope-motor e do sistema convergente, além de verificarem a funcionalidade da adesão entre o propelente e a borracha. Especificamente para o trabalho aqui apresentado, serão analisados apenas resultados inerentes à avaliação do inserto da tubeira e deterioração da borracha EPDM na interface com o inserto de grafite para um tempo de ensaio de $56 \mathrm{~s}$. Foi verificada, após ensaios, a presença de não conformidades em componentes do motor, que, posteriormente, levaram a uma análise criteriosa de suas causas e a implementação de soluções para reprojeto de componentes visando, assim, aumentar a segurança e garantir a integridade estrutural do motor-foguete para continuidade dos ensaios.

Palabras clave: VLM-1. Ensaio de queima. Motor-teste cigarro. Inserto de grafite.

\section{INTRODUCTION}

The capability to design, manufacture and test rocket engines is considered strategic for the countries that develop spatial activities, assuring them the possibility to design their rockets, independently of external political influences.

Throughout the years, the experience obtained by the Institute of Space and Aeronautics, has shown that purchasing rocket engines and their components from foreign countries is an extremely delicate task, since the technology of rockets is subject to the restriction of the countries that signed the Missile Technology Control Regime (MTCR), in addition to experiencing embargoes of political, commercial and strategic origins (TORRES et al., 2009).

In order to overcome these obstacles, the DCTA/ IAE has been seeking to develop their own motors in order to become independent from external influences. Many efforts have been made some of them in the research of new materials and processes, as well as in numeric and computational tools for the development of systems that integrate the rocket motors. At DCTA/ IAE, the tool used specifically for the development of the Thermal Protection System (TPS) of the engine S50 solid rocket motor, dedicated to the Microsatellite Launch Vehicle (VLM-1), has been a subscale solid rocket motor, so called test-motor, for the acquisition of the thermal and ablative materials characteristics used in solid rocket motor. The purpose of this engine is to evaluate the behavior of the material of the insert to be used in the nozzle, and the formulation of the ethylene propylene diene monomer (EPDM) rubber used for the thermal insulation of the cylindrical part of motor case and also of the convergent section of the nozzle.

In Figure 1, we can see the subscale solid rocket motor nozzle, the object of this study. Schematically, we have the tip (item 01), the convergent back cover (item 02) and the composite insert (item 03). In the convergent section of the nozzle (item 02), on Figure 1, an EPDM insulation layer is also molded, which is susceptible to deterioration in the connection with the insert. Therefore, this work will present a study to investigate the erosion of the rigid thermal protection (insert) in the convergent section and the deterioration of the EPDM rubber in the interface with the insert observed during the engine static firing for a time of $56 \mathrm{~s}$. 
Figure 1 - Test engine nozzle. (1) Steel tip; (2) Convergent back cover and (3) insert.

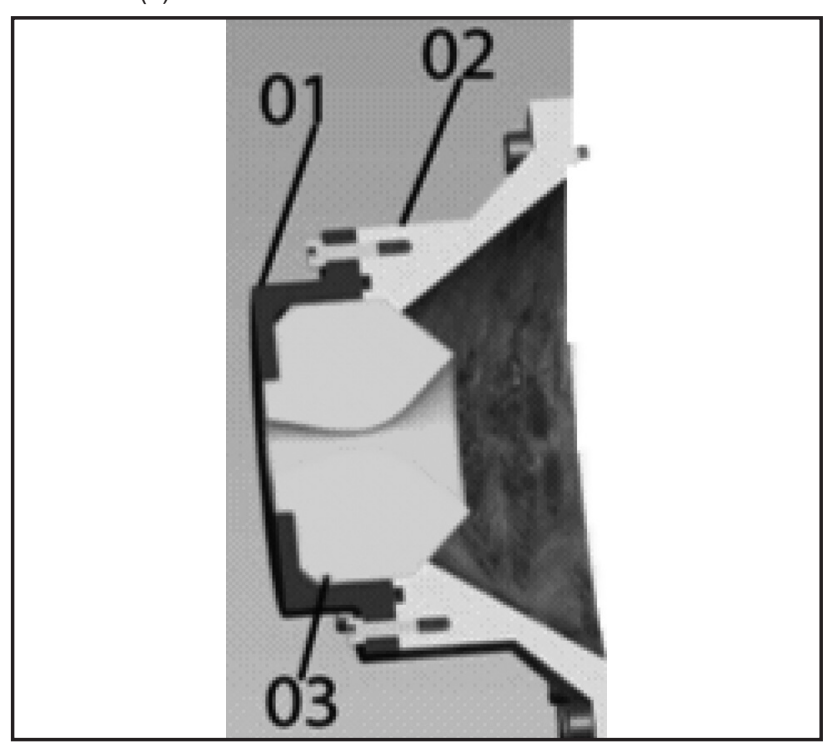

Source: The author.

This erosion can bring undesirable consequences regarding the safety and the integrity of the rocket motor, which may compromise the mission.

\subsection{Solid-propellant rocket motor}

The rocket motors developed at DCTA/IAE have chemical propulsion systems, in which the combustion reaction of the solid propellant generates thermal energy in the form of gases at high temperature and high pressure. The gases generated in the combustion chamber are ejected through the nozzle, where the conversion of thermal energy into kinetic energy occurs, thus generating thrust for the propulsion of the rocket. (SUTTON, 1992).

Space vehicles propellers are loaded with highly energetic propellants, preferably with high density, which provide high specific impulse and reduce the volume of the tanks or the motor case. A rocket motor powered by solid propellant is constituted basically motor case, structured in metallic material or winding in composite material with of carbon fibers/epoxy resin to support the internal pressure, loaded with propellant, and with propellant grain geometry adequate to the rocket's performance specifications. The De Laval-type nozzle, integrated to the back part of the engine, is constituted of a convergent and divergent section (SUTTON, 1992). It is the component responsible for expansion and acceleration of the gases until the engine reaches supersonic speeds (Mach > 1) in the exit section, transforming the enthalpy of the propellant into kinetic energy. The pressure generated inside the combustion chamber may reach $10 \mathrm{MPa}$, resulting in thrust of the order of a hundreds of tons-force. In the rocket motor there is a thermal liner constituted of layers of rubber between the motor casing and the solid propellant, with the purpose of preventing heat transfer from the high temperature gases to the structure of the rocket (SCIAMARELI et al., 2002).

At DCTA/IAE, a a sub-scale solid propellant rocket motor is used, for the quality control of the propellant burning rate and of the specific energy of the propellants. These subscale motors have propellant grain geometry with radial burn and star profile, and burning time between two and four seconds, depending on the type of propellant used and on the operating pressure in the combustion chamber.

For the purpose of this study, the same metallic case of this sub scale motor was used. The main changes made were in the geometry of the propellant grain that uses the end burning grain, in order to obtain tests with different burning times needed for the evaluation of the materials, and also the diameter of the nozzle throat, with the objective of maintaining the pressure at $8 \mathrm{MPa}$ in the combustion chamber. In this configuration rocket motor is constituted of the following components: metallic casing, thermal protections, nozzle, propellant and igniter. This rocket motor's nozzle is composed of metallic tip, convergent back cover, insert, thermal insulation rings and front cover. A cylindrical tube made out of EPDM rubber is used to protect the metallic case during the operation. The solid propellant is a heterogeneous mix with rubbery composed by hydroxyl terminated polybutadiene (HTPB) resin and ammonium perchlorate as an oxidizer, powdered aluminum used to raise the temperature of the gas temperature, in addition to other components in smaller percentages, used to improve the mechanical properties, as well as to adjust the burning rate to the desired conditions.

Figure 2 shows a simplified scheme of the subscale motor test. This motor is composed of a metallic case, manufactured in steel SAE 4140, with length of 250 or $500 \mathrm{~mm}$, depending on the burning time specified for each test, internal diameter of $156 \mathrm{~mm}$, wall thickness of $5 \mathrm{~mm}$, potassium nitrate tablets pyrotechnic igniter, nozzle insert in graphite, and metallic casing internally lined with an EPDM rubber tube to support the thermal load generated by high gas temperature.

For the thermal insulation of the metallic case, the EPDM rubber is molded and vulcanized in a matrix 500 $\mathrm{mm}$ long and with a thickness of $15 \mathrm{~mm}$ in all of its extension. After vulcanization, the rubber is machined in the desired length, with an external diameter of 156 $\mathrm{mm}$ and an internal diameter of $126 \mathrm{~mm}$. Then, this rubber tube is inserted in the metallic case so that it is ready for propellant loading. The adhesion of the propellant to the tube is achieved by applying primer before loading.

After loading the propellant in the rubber tube, the set is then taken to the process of curing in a furnace 
at a predetermined temperature, following a thermal cycle in which the propellant achieves the consistency of an elastometer suitable for use.

The burning of solid propellant produces gases at a temperature up to $3200 \mathrm{~K}$ and a pressure of $8 \mathrm{MPa}$ in the combustion chamber, which are ejected through the nozzle at speeds $\geq 2100 \mathrm{~m} / \mathrm{s}$ for thrust generating.

According to Bucley

\begin{abstract}
The space race perpetrated during the Cold War was the reason behind the demand for materials of extreme applications, where mechanical properties should meet the requirements of use in high temperatures ( $\left.\mathrm{T}>1000^{\circ} \mathrm{C}\right)$. (BUCLEY, 1993 apud GONÇALVES; PARDINI, 2009, p. 232).
\end{abstract}

The metallic alloys, in the form of special steels, would partially fulfill this requirement because, despite the good mechanical resistance, that is, tensile resistance limit $\left(\sigma_{\mathrm{T}}>500 \mathrm{MPa}\right)$ and the elastic module $(\mathrm{E}>100 \mathrm{GPa})$, they present high specific mass $\left(\varrho=7.8 \mathrm{~g} / \mathrm{cm}^{3}\right)$ for steels, when subjected to long-term service flow stress. Mass relief without sacrificing mechanical properties is crucial in space vehicles systems and structures. Thus, the researches were gradually oriented in the direction of obtaining lighter materials that also present thermomechanical resistance suitable to the applications which require these conditions.

Therefore, the firing tests of subscale motors (Figure 2) allow the determination of the ablative characteristics of the insert materials (item 03 on Figure 1) in relation to the operating time, simulating the previously mentioned operation time and combustion chamber pressure in the real scale rocket motor, besides evaluating the deterioration of the insert materials.

Figure 2 - Half-cut illustration of the test engine. Item 01: Steel tip; Item 02: Convergent back cover; Item 03: Insert; Item 04: Engine casing; and Item 05: Locking front cover.

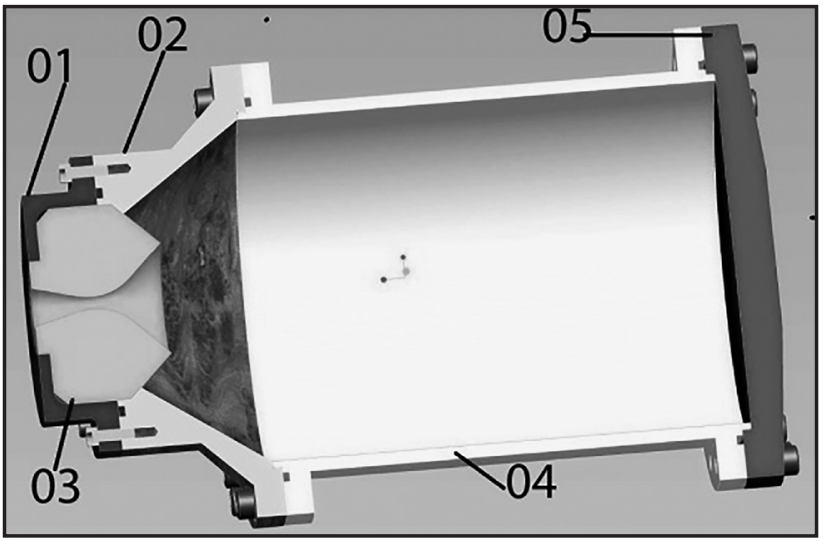

Source: The author.

\subsubsection{Insert}

The insert shown in Figure 3 can be manufactured from composite materials of carbon fiber-reinforced carbon (CFRC) or from hybrid CFRC composites modified with Silicon Carbide (SiC), or, in the specific case of this work, with graphites. These materials are characterized by their high emissivity $(\varepsilon>0.8)$, which allows for an increased performance in the transference of energy absorbed from the environment, relieving the metallic material of the metal tip from remaining exposed to high temperatures for a long time and extending its lifespan.

Figure 3 - Composite/graphite insert.

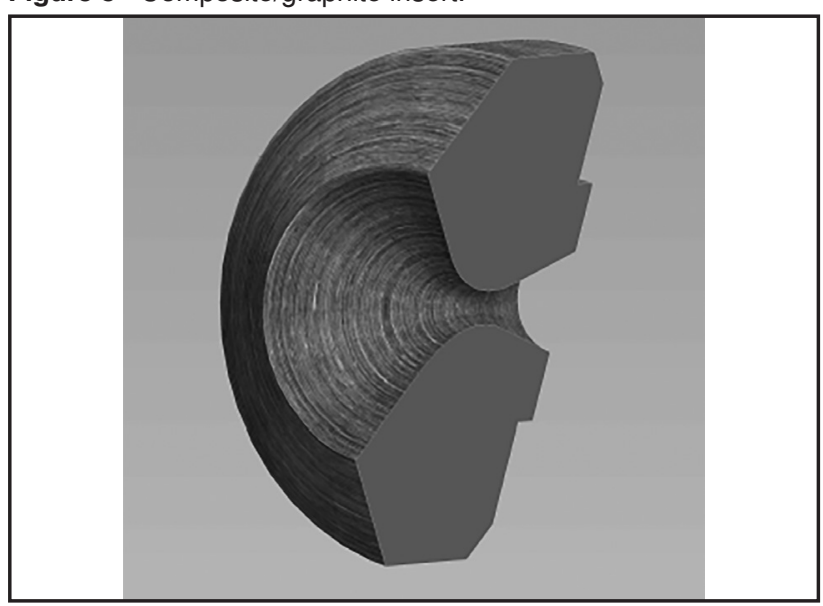

Source: The author.

Composites are materials that consist of two or more distinct phases on a macroscopic scale, in which the mechanical performance and the properties are designed in such a way that as to achieve a superior performance when compared to the individual properties of each component. One of the phases, which is discontinuous, is the reinforcement, and its main function is to support the stress applied. The phase responsible for the joining or agglutination of the reinforcements, as well as for their transference and distribution, is the matrix. From the microscopic point of view, the physical-chemical interactions between the matrix and the reinforcement, called interface/interphase, are also considered an additional phase (DANIEL; ISHAI, 1994).

The aerospace industry, in particular, was largely responsible for boosting the development of composite materials, making use of the good mechanical properties, of the low specific mass, and contemplating the possibility of weight reduction compared to the existing metal alloys. The first steps to the use of composites in the aerospace industry were taken in 1960, with the development of boron filaments (NATIONAL AERONAUTICS AND SPACE ADMINISTRATION, 1974). 
In the aerospace industry sector, composites distinguish themselves for the superiority of the applications and the engineering applied to new solutions in terms of materials and also of process, which explains the high added value in terms of market value. In this type of industry, the composite materials perform a fundamental role, mainly related with nozzle throats of propulsion systems of launch vehicle with solid propellant rocket motors. In this subsystem, the gases resulting from this process present high temperatures (above $2000{ }^{\circ} \mathrm{C}$ ) and are expanded in the nozzle throat, whose function is to propitiate the increase in the velocity of the ejection $(\geq 2500 \mathrm{~m} / \mathrm{s}$ ), which is a significant factor to the thrust. These components are made from refractory materials, which are resistant to thermal shock and to the erosion that happens during the operation of the launch vehicle.

The material most used during the 1970's was graphite, which satisfactorily met the requirements in terms of operation and dimensions. As rocket motors had their geometries increased, graphites ceased to meet the specifications, whether by their limited properties, or by the limitation in the size of the piece. Thus, by the end of the 1970's, the use of CFRC composites was introduced (McALLISTER; LACHMAN, 1982). The arrival of the CFRC composites met the current design requirements.

The initial goal of qualifying a methodology to analyze the ablative characteristics of the graphite insert led to the evaluation of the CFRC composite inserts, finalizing the methodology of qualification.

After the methodology was qualified, tested and approved, the CFRC-SiC material development stage was initiated, a collaboration between the DCTA/IAE and the Deutschen Zentrums für Luft- und Raumfahrt (DLR - German Aerospace Center). The DCTA/IAE would be responsible for the use of the process of liquid polymer infiltration, while the DLR would carry on with the liquid silicon infiltration. These processing routes are schematically presented in Figure 4. The DLR and the DCTA/IAE already have a long history of success in the development of the rockets VS-30, VS-30 ORION and VSB-30. Therefore, the two organizations have a mature relationship, based on common interests and in the division of responsibilities and costs.

Figure 4 - Simplified schematic diagram of the steps of carbon fiber composite processing reinforced with the C-Sic hybrid matrix. The temperatures shown refer to the temperature of the process.

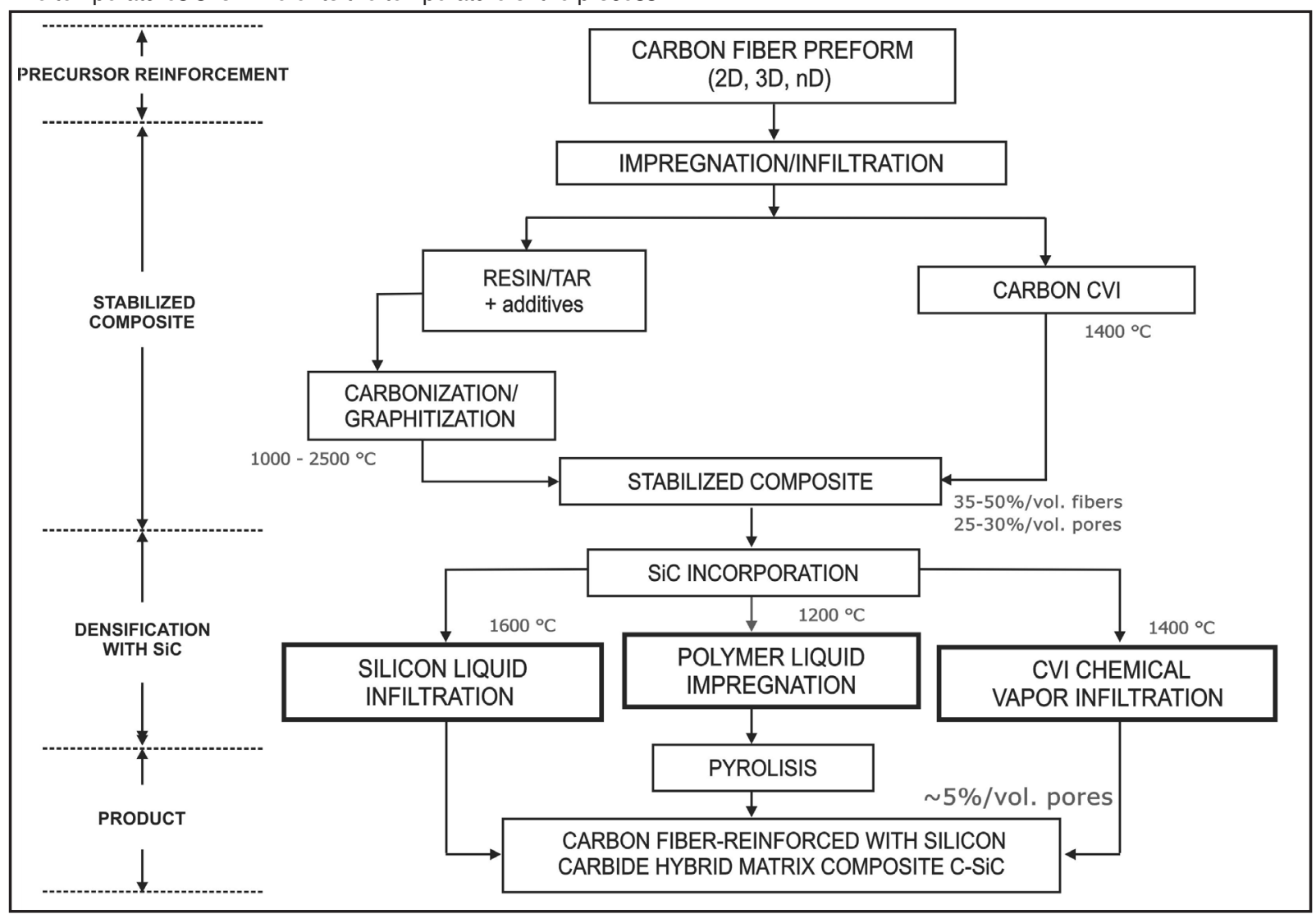

Source: Adapted from Pardini and Gonçalves (2009, p. 233). 
According to Gonçalves (2008), the CFRC composite's thermal, mechanical, ablative and erosion resistance properties will define the type of stress suited to the application that is aimed. Thus, for this work, the four-directional flat preform (4D) was defined for the DCTA/IAE to develop. These performs present a specific mass that varies between $0.5 \mathrm{~g} / \mathrm{cm}^{3}$ to $1.0 \mathrm{~g} / \mathrm{cm}^{3}$ and about $40-50 \%$ of porosity.

At DCTA/IAE, the beginning of the composite's manufacturing process is presented on Figure 5 for the composite 4D CFRC-SiC, in which the assemblage of the skeleton structure of the preform will be the basic structure for the process of densification (KRATSCH, 1981; MAISTRE; EITMAN, 1976). The 4D preforms are manually assembled in a similar manner to the assemblage of Legos, resulting in the geometric form of the component that one wishes to obtain. The assemblage of the preform is made on a template. Initially, the rods are displayed perpendicularly to the flat surface, as shown on Figure 5(a), in the positions defined on the template.

Since the preform was projected so that the rods $(\varnothing=2 \mathrm{~mm})$ juxtapose each other in 4 directions, the configuration of the rods on the flat surface assumes the shape of Figure 5(b).

Figure 5 - Preform. (a) Beginning of the assemblage of the 4D-flat preform by positioning the rods vertically on a polyurethane foam template. (b) View of the positioning of the rods on the 4D-flat preform in the directions $0 / \pm 60^{\circ}$.

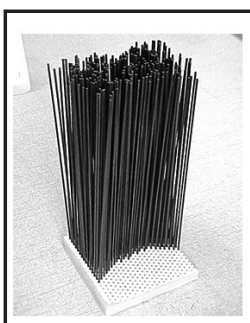

(a)

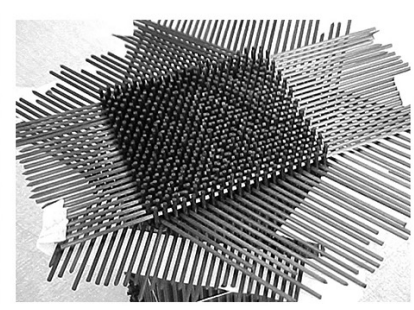

(b)
Source: The author.

Figure 6 shows the sequence of the building process of the thickness of the preform, in which the rods are positioned on a horizontal plane. In this stage, the thickness is continuously built. It is important to emphasize that this is a very labor intensive process, since it involves a significant amount of time, and it must be carefully conducted in order to avoid mistakes in the positioning of the predefined directions.
Figure 6 - Detail of the positioning of the rods on the plane of 4D-flat preform.

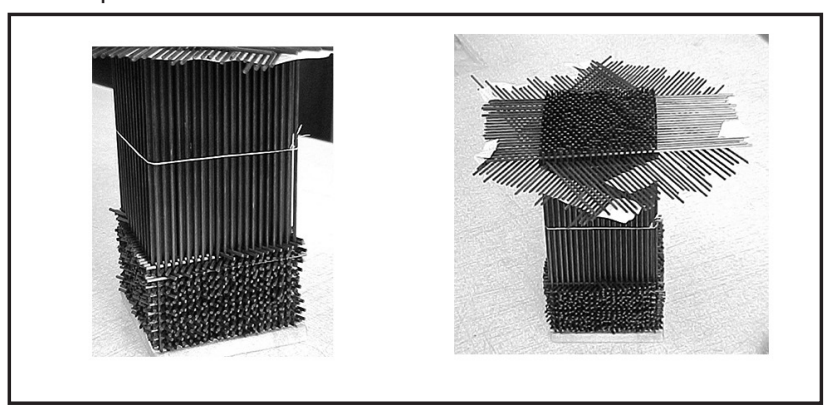

Source: The author.

Figure 7 shows the final manufacturing stages of the flat 4D-flat perform. The rods' arrangement is completed all the way to the top, as shown in Figure 7(a) and (b). At this point, in order to keep the rods in their positions, avoiding any shifting, and to conduct the impregnation process, it is first necessary to apply a quick-drying adhesive on the surface of the perform.

Figure 7 - (a) Thickness construction. (b) Concluded preform.

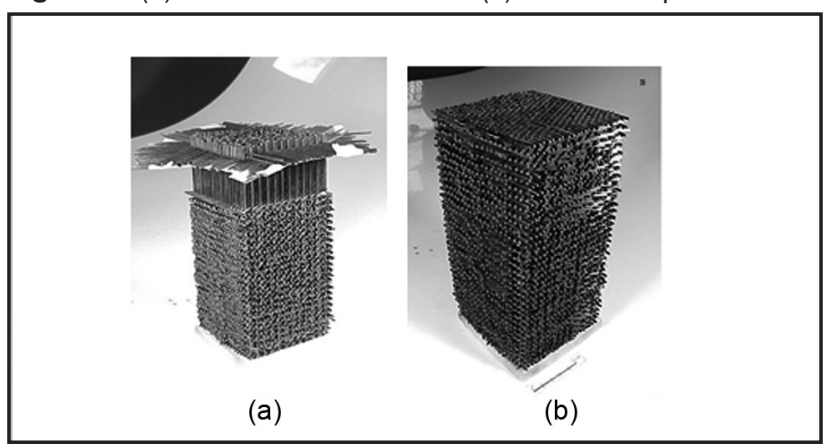

Source: The author.

In order to obtain the stabilized composite, as shown on Figure 4, the assembled preform is impregnated with a phenolic resin and subjected to multiple subsequent cycles of impregnation/ carbonization in order to reach a specific mass that may be up to $1.90 \mathrm{~g} / \mathrm{cm}^{3}$, for structural applications (PARDINI; GONÇALVES, 2009).

In the DCTA/IAE development, the densification with $\mathrm{SiC}$ would involve the use of a silicone polymer to fill the pores and micro cracks resulting from the carbonization process (1000 $\left.{ }^{\circ} \mathrm{C}\right)$. At the end of the process, pores and micro cracks must represent about 5\%/volume, which is the maximum acceptable limit for applications to be used in nozzle throats and thermal protections of atmospheric reentry (PARDINI; GONÇALVES, 2009). 


\section{METHODOLOGY}

In the test engine firing tests performed at DCTA/ IAE, for a period of $56 \mathrm{~s}$, two main problems were observed when trying to determine the ablative characteristics of the possible materials to be used as the nozzle's insert/throat for the engine of the microsatellite launch vehicle. The first was the heating of the outer part of the steel tip, characterized by an oxidized aspect of the metal, as shown in Figure 8.

Figure 8 - Image of steel tip after static firing test.

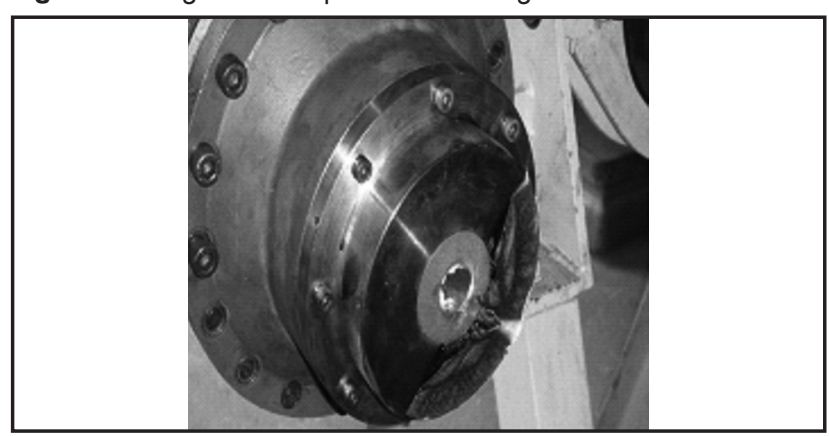

Source: The author.

The conclusion of the analysis was that this heating was caused by the heat transfer from the gases of the propellant's combustion to the material of the nozzle insert, and from the material of the nozzle insert to the metallic part. This fact was evaluated as critical, and the use of a thermal barrier was decided upon; it would be made of carbon fibers/phenolic resin composite and placed on the interface between the metallic tip and the insert.

The second problem was an intense degradation of the thermal protection in EPDM on the interface between the graphite insert and the rubber of the convergent back cover, as shown in Figure 9.

Figure 9 - Deterioration of the rubber in the convergent back cover after static firing test.

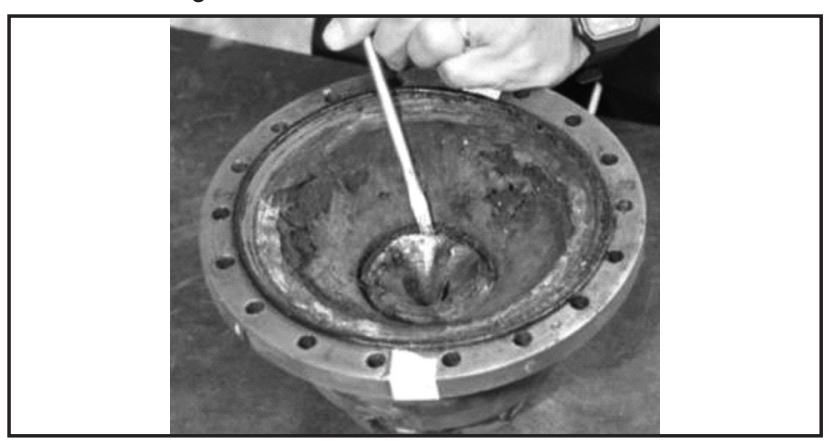

Source: The author.

After the analysis of the rubber, it was concluded that the origin of the observed problem is an overheating due to the high temperatures of the gases released during the engine firing, which, in contact with the graphite, overheats this area, leading to the degradation of the rubber. This heating compromises the safety of the test, since it may lead to the rupture of the convergent back cover due to the degradation of the mechanical properties of the steel. A modification on the design of the steel tip was then agreed upon, (Figure 10) in such a way as to adopt a rigid thermal protection, made of carbon fiber/phenolic resin, on that interface in order to decrease the heat transfer.

Figure 10 - Illustration of the tip (in half cut).

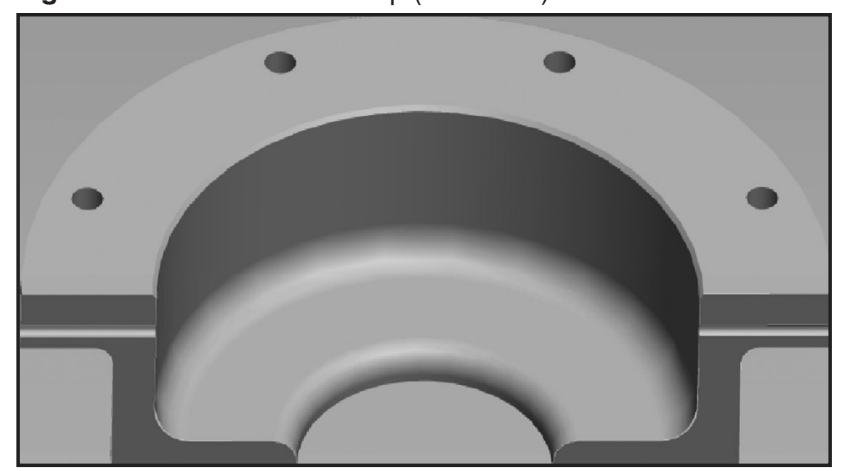

Source: The author.

In order to solve the heating problem, the following methodology was used: a rigid thermal barrier made out of a composite of carbon fiber/ phenolic resin was added to the tip on the interface of the insert with the metallic parts. The modified tip and the carbon fiber/phenolic resin thermal barrier are shown in Figure 11 (a) and (b).

Figure 11 - Image of the modified tip. (a) Steel tip and thermal barrier. (b) Tip integrated to the thermal protection.

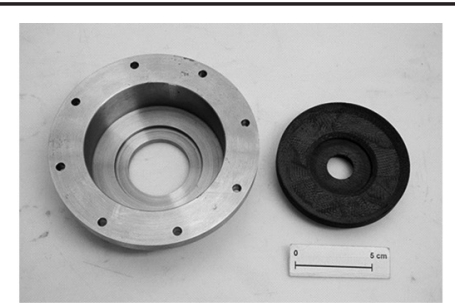

(a)

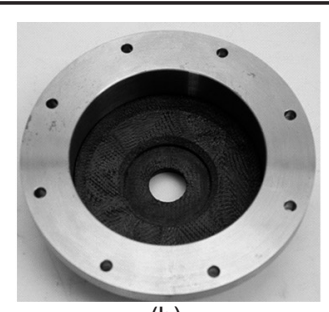

(b)
Source: The author.

On the graphite insert, a machining of the external diameter was made, and a thermal barrier made of a composite of carbon fiber/phenolic resin was added to the interface between the insert and the metallic part of the tip. The set, that is, the modified insert with the rigid thermal barrier, is presented on Figure 12. 
Figure 12 - Composite material/graphite insert with thermal barrier.

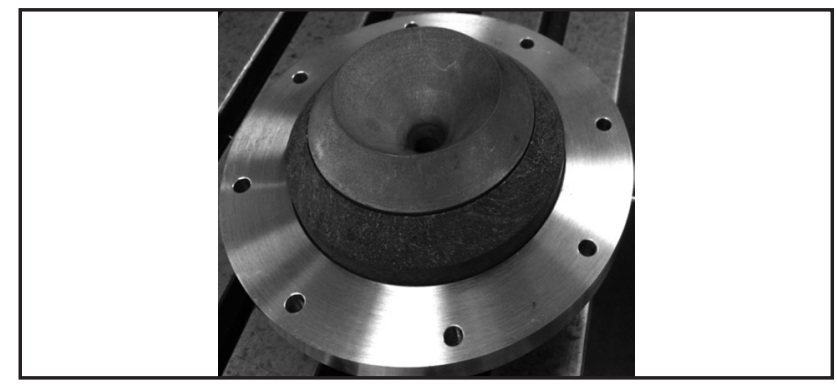

Source: The author.

The solution for the second problem was to adopt a Rigid Thermal Protection (RTP), also made of carbon fibers/phenolic resin, to the convergent back cover on the interface between the insert and the rubber, as seen in Figure 13 (a) and (b).

Figure 13 - Rigid thermal protection used. (a) Upper view. (b) Side view.

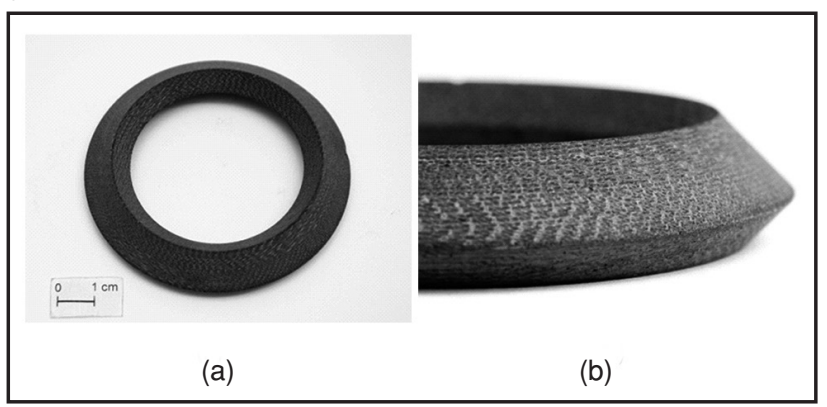

Source: The author.

Figure 14 shows, schematically, the rocket engine with the modifications.

Figure 14 - Half cut illustration of test engine with modified nozzle. Item 01: Redesigned steel tip; Item 02: Tip's thermal barrier; and Item 03: Thermal protection surrounding the insert.

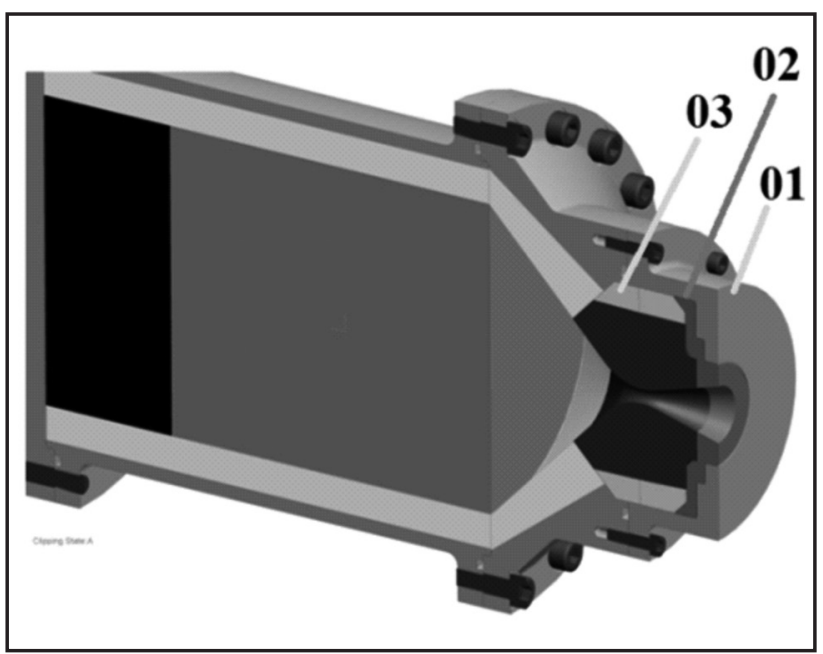

Source: The author.

\section{RESULTS AND DISCUSSION}

The results of the performed tests, considering the solution of the mentioned problems and the test time of $56 \mathrm{~s}$, were satisfactory. The thermal protections, manufactured in carbon fiber/phenolic resin composite, are highly effective, to be used as thermal barriers in systems with elevated thermal requirement. As in rocket motors, the metallic materials such as steel and aluminum are used as structural elements to withstand high levels of internal pressure, and their utilization as thermal protection has become essential to preserve their mechanical characteristics. The problems presented were solved by adopting a Rigid Thermal Protection during the firing tests, as seen in Figures 12 and 13.

In these tests, thrust curves in the motor axis in relation to time were obtained in order to determine the force generated by the rocket motor, its propulsive characteristics, and the ballistic characteristics of the propellant. Dimensional measurements were taken in order to map the internal profile of the insert and of the convergent section (in EPDM rubber) that lines the back cover. The results obtained specifically for the purposes of the present work are shown in Figures 15 and 16.

In Figure 15, we can see that the problem presented in Figure 8 was completely solved by inserting the thermal protections. We can see in this image only the accumulation of soot on the steel tip, resulting from the burning of the propellant, and the thermal effect of the gases on the metallic part of the nozzle were eliminated.

Figure 15 - Test engine on test bench after firing test.

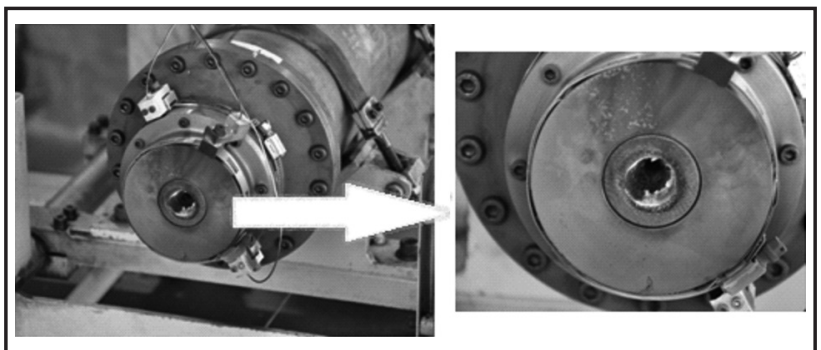

Source: The author.

In Figure 16, we can see that the problem presented in Figure 9 was also completely solved with the implementation of the solution proposed in this work. In this image, we can observe that there was no deterioration of the EPDM rubber in the interface with the graphite insert after the test. 
Figure 16 - Internal area of the nozzle after firing test.

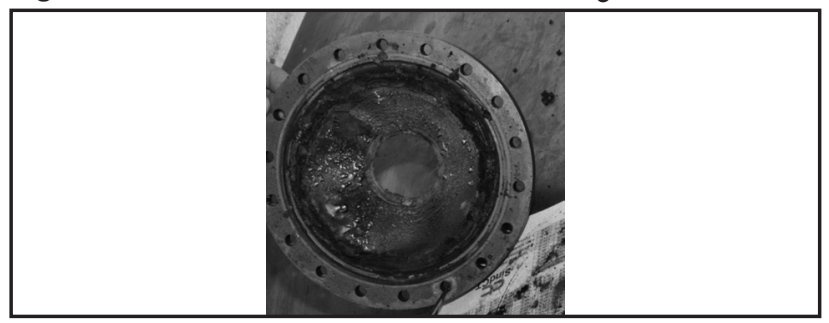

Source: The author.

The temperature of the insert's material, during the engine's $56 \mathrm{~s}$ operation, was monitored by thermocouples, as shown in Figure 17. Three thermocouples were installed in three parts of the insert at a depth of $25 \mathrm{~mm}$, and the maximum temperature observed on the insert in these parts was $1000^{\circ} \mathrm{C}$.

\section{CONCLUSIONS}

The results obtained from the test, with the adoption of the design solutions of the nozzle pieces, showed a significant decrease in the temperature of the metal parts that surround the graphite insert, thus leading to the conclusion that the adoption of thermal protections in carbon fiber/phenolic resin composite between the insert and the metal was effective as a thermal barrier. It was also verified that the use of a Rigid Thermal Protection on the convergent, in the connection between the rubber and the graphite, eliminated the rubber erosion, as seen, in Figures 15 and 16 , respectively.

Therefore, the results show that once the solution with thermal protections for a time of $56 \mathrm{~s}$ was adopted, the observed problems were eliminated; the solution may be utilized by DCTA/IAE researchers in all the subsequent tests of this work with graphite insert, independently of the firing time.

\section{ACKNOWLEDGEMENTS}

The authors would like to thank the manager of VLM-1, Dr. Luis Eduardo Vergueiro Loures da Costa, for the financial support; the Divisions of Chemistry (AQI), Mechanics (AME), Materials (AMR) and Integration and Tests (AIE) of Instituto de Aeronáutica e Espaço ("Institute of Space and Aeronautics"); and the company CENIC for the cooperation and the technical support in the preparation of the components and in the execution of the tests.

Figure 17 - Curve of the insert's temperature obtained by thermocouple. $\mathrm{CH}$ identifies the measurement channels, and the image on the right, the positioning of the thermocouples in the engine.

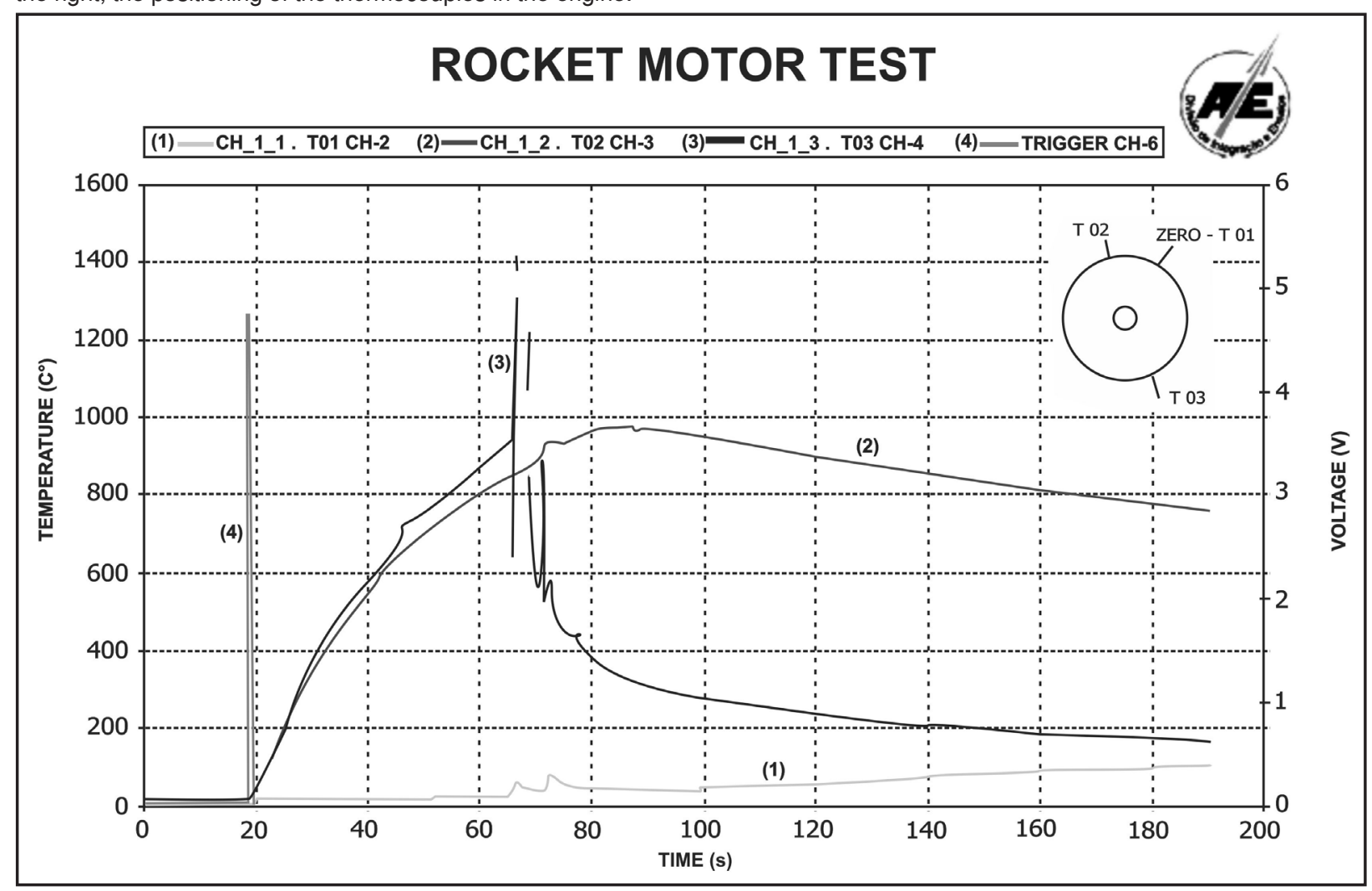

Source: The author. 


\section{REFERÊNCIAS}

DANIEL, I. M.; ISHAI, O. Engineering mechanics of composite materials. New York: Oxford University Press, 1994.

GONÇALVES, A. Caracterização de materiais termoestruturais a base de compósitos de carbono reforçados com fibras de carbono (CRFC) e carbonos modificados com carbeto de silício (SiC). 2008. 226 f. Tese (Doutorado)-Curso de Pós-Graduação em Engenharia Mecânica e Aeronáutica, Instituto Tecnológico de Aeronáutica, São José dos Campos, SP, 2008.

KRATSCH, K. M.; EITMAN, D. A. Method for fabricating a reinforced composite. United States patent US 4252588, 24 Feb. 1981.

MAISTRE, M. A. Development of a 4D reinforced carbon-carbon composite. American Institute of Aeronautics and Astronautics (AIAA), p. 76-607, 1976.

MCALLISTER, L. E.; LACHMAN, W. L. Multidirectional carbon-carbon composites. In: HANDBOOK of composite. New York: Elsevier Science Publishers, 1983. v. 4. p. 109-175.

NATIONAL AERONAUTICS AND SPACE ADMINISTRATION. Advanced composite materials - vehicle design criteria. 1974. Report SP8108.

PARDINI, L. C.; GONÇALVES, A. Processamento de compósitos termoestruturais de carbono reforçado com fibras de carbono. Journal of Aerospace Technology and Management, São Paulo, v. 1, n. 2, p. 231-241, July/Dec. 2009.

REIS, R. I.; SHIMOTE; W. K. Ensaios da primeira configuração de motores testes com propelente PC01 e inserto de grafite para testes de desenvolvimento da tubeira e proteções térmicas do motor S50 do veículo Lançador de Microssatélites (VLM-1). São José dos Campos - SP: Instituto de Aeronáutica e Espaço, 2014. Relatório de Ensaio (DCTA/IAE) n. 593-111200/E0001.

Ensaios da segunda configuração de motores testes para desenvolvimento de insertos de tubeira e proteções térmicas do motor S50. São José dos Campos - SP: Instituto de Aeronáutica e Espaço, 2015. Relatório de Ensaio (DCTA/IAE) n. 001/APE/2015.

SCIAMARELI, J.; TAKAHASHI, M. F. K.; TEIXEIRA, J. M. Propelente sólido compósito polibutadiênico: I- influência do agente de ligação. Química nova, v. 25, n. 1, p. 107-110, 2002.

SUTTON, G. P. Rocket propulsion elements. 8. ed. New York: Wiley, 1992.

TORRES, M. F. C. et al. Propulsão líquida no IAE: visão das atividades e perspectivas futuras. Journal of Aerospace Technology and Management, São Paulo, v. 1, n. 1, p. 99-106, jan./jun. 2009. 